\begin{tabular}{|l|l|l|}
\hline \multicolumn{2}{|c|}{ PublisherInfo } \\
\hline \hline PublisherName & $:$ & BioMed Central \\
\hline \hline PublisherLocation & $:$ & London \\
\hline \hline PublisherImprintName & $:$ & BioMed Central \\
\hline \hline
\end{tabular}

\title{
OPGL - the link between T cell activation and bone loss
}

\begin{tabular}{|l|l|l||}
\hline \multicolumn{2}{|c||}{ ArticleInfo } \\
\hline \hline ArticleID & $:$ & 197 \\
\hline \hline ArticleDOI & $:$ & $10.1186 /$ ar-2000-66794 \\
\hline \hline ArticleCitationID & $:$ & 66794 \\
\hline \hline ArticleSequenceNumber & $:$ & 154 \\
\hline \hline ArticleCategory & $:$ & Paper Report \\
\hline \hline ArticleFirstPage & $:$ & 1 \\
\hline \hline ArticleLastPage & $:$ & 4 \\
\hline \hline & & RegistrationDate : 2000-3-23 \\
\hline ArticleHistory & $:$ & OnlineDate \\
\hline \hline ArticleCopyright & $:$ & Current Science Ltd2000-3-23 \\
\hline \hline ArticleGrants & $:$ & \\
\hline \hline ArticleContext & $:$ & 130753311 \\
\hline \hline
\end{tabular}




\section{Keywords}

Adjuvant, osteoclast, osteoporosis, T lymphocyte

\section{Context}

It has long been recognised that chronic inflammatory diseases are associated with osteoporosis. In addition, inflammatory arthritis is associated with periarticular osteoporosis and the destruction of articular cartilage and bone. Although a number of cytokines have previously been implicated in bone homeostasis, the mechanism by which immune activation leads to bone loss has been a mystery. Osteoprotegerin ligand (OPGL; also known as RANKL, TRANCE and ODF) is a member of the tumour necrosis factor family. It binds to its receptor, RANK, on the surface of osteoclast precursors, mature osteoclasts and chondrocytes. Ligation of RANK by OPGL causes osteoclast maturation and promotes bone resorption. This interaction is regulated by a soluble decoy receptor, OPG, which ligates OPGL and prevents bone loss. The authors have previously shown that OPG-deficient mice have severe osteoporosis, whereas OPGL-deficient mice exhibit increased bone density, with obliteration of the bone marrow cavity; this disorder resembles osteopetrosis (marble bone disease) in humans.

$\mathrm{T}$ cells are induced to express both membrane-bound and soluble OPGL following ligation of the $\mathrm{T}$ cell receptor (TCR) and this paper explores the significance of this for bone metabolism in inflammatory arthritis.

To investigate whether activated $\mathrm{T}$ cells can promote osteoclast maturation and whether blockade of the OPGL/RANK interaction influences the natural history of a rat model of inflammatory arthritis.

\section{Significant findings}

Both fixed activated $\mathrm{T}$ cells and the supernatant from activated $\mathrm{T}$ cell culture promoted the maturation of osteoclasts. This was blocked by the addition of OPG to the culture, indicating that the osteoclast precursors were responding to both soluble and membrane-bound OPGL. CTLA4-/- mice were severely osteoporotic. Eight weeks after transfer of CTLA4-/- T cells into RAG1-/- mice, the recipient mice exhibited reduced bone mineral density, an increased density of TRAP ${ }^{+}$osteoclasts in bone and resorption of trabecular and cortical bone. Transfer of CTLA4-/- T cells into OPGL-/- mice produced the 
same effect, indicating that OPGL expression by the activated T cells was sufficient to induce osteoclast maturation. Daily injection of CTLA4-/- mice with the decoy receptor, OPG, increased bone mineral density and decreased the density of $\mathrm{TRAP}^{+}$osteoclasts in bone.

Adjuvant arthritis (AA) in Lewis rats is characterised by severe joint inflammation with local bone and cartilage destruction and therefore shares many features with RA in humans. In Lewis rats, OPGL was expressed on the surface of activated T cells at the time of disease onset. Daily injection of OPG in rats for 7 days following the onset of AA resulted in striking bone and cartilage preservation, compared to that for the non-treated arthritic animals. However, neither paw swelling nor the inflammatory infiltrate were reduced by OPG treatment.

\section{Comments}

The recent body of work produced by this group has enormous clinical significance because it appears to have defined a pivotal mechanism underlying several disorders of bone metabolism, including periarticular osteoporosis in rheumatoid arthritis (RA), systemic osteoporosis in chronic inflammatory conditions, and the rare disease osteopetrosis. It should be emphasised that the administration of OPG appears to have no effect on the severity of joint inflammation, but rather offers the prospect of preserving ossified joint architecture, thereby extending the window of opportunity for controlling inflammatory arthritis and preventing ultimate joint destruction.

\section{Methods}

To assess whether activated $\mathrm{T}$ cells could promote osteoclast maturation in vitro, haematopoietic bone marrow precursors from wild-type mice were cultured, in the presence or absence of OPG, with either activated $\mathrm{CD}^{+}{ }^{\mathrm{T}}$ cells fixed with paraformaldehyde or with supernatant from activated $\mathrm{T}$ cell culture. Mature osteoclasts developing in these cultures were identified by their expression of tartrate-resistant acid phosphatase (TRAP), cathepsin K, calcitonin receptor, RANK and ?3-integrin. The effect of activated T cells on osteoclast development was also studied in vivo, using CTLA4-deficient mice, in which $\mathrm{T}$ cells become spontaneously activated. T cells from CTLA4-/- mice were also adoptively transferred to RAG1-deficient mice (which lack their own T cells). The bone mineral density in the mice was assessed by computed tomography of tibial bones and bone histology was analysed.

\section{Additional information}

OPGL also regulates lymph node organogenesis and lymphocyte development (Kong et al Nature 1999, 397:315-23) and may play a role in the development of aberrant immune responses. 


\section{References}

1. Kong YY, Feiger U, Sarosi I, Bolon B, Tafuri A, Morony S, Capparelli C, Li J, Elliott R, McCabe S, Wong T, Campagnuolo G, Moran E, Bogoch ER, Van G, Nguyen LT, Ohashi PS, Lacey DL, Fish E, Boyle WJ, Penninger JM: Activated T cells regulate bone loss and joint destruction in adjuvant arthritis through osteoprotegerin ligand. Nature. 2000, 402: 304-309.

This PDF file was created after publication. 